\title{
Análisis experimental de uniones con barras de acero encoladas en maderas de castaño y elondo
}

\section{Experimental analysis of bonding in steel bars glued into chestnut and tali timber}

\author{
D. Otero Chans ${ }^{(*)}$, J. Estévez Cimadevila(*), E. Martín Gutiérrez ${ }^{*}$
}

Recepción/Received: 21-II-08

Aceptación/Accepted: 27-XI-08

Publicado online/Online publishing: 4-III-10

\section{RESUMEN}

En el presente artículo se resumen los resultados de una amplia campaña experimental encaminada a evaluar la influencia de los distintos parámetros geométricos y mecánicos en la capacidad resistente de uniones realizadas con barras roscadas de acero encoladas en madera aserrada de frondosa. Los estudios existentes en el campo de las uniones encoladas en madera se han centrado fundamentalmente en el análisis de uniones realizadas en madera laminada de especies coníferas. Con objeto de evaluar la influencia de las características de la madera en la capacidad resistente de la unión se ensayaron probetas realizadas con dos especies de madera frondosa de características físicas y mecánicas muy diferentes. Se utilizaron diversas configuraciones geométricas. Un total de 190 probetas han sido ensayadas hasta rotura.

Los valores de carga de rotura alcanzados por las probetas se han comparado además con los valores de cálculo propuestos por el Eurocódigo 5, en su versión de borrador final prEN 1995-1-1(2001).

Palabras clave: uniones encoladas, diseño de uniones, adhesivos para madera, ensayos destructivos, madera de frondosa.

\section{SUMMARY}

This article summarizes the results of an extensive experiment designed to determine the effect of geometric and mechanical parameters on the axial strength of the bonds formed when threaded steel bars are glued into sawn hardwood timber. The studies conducted to date on glued wood joints have focused primarily on softwood glued laminated timber or glulam. In the present study, specimens made from two hardwood species with very different physical and mechanical properties were used to evaluate the effect of wood characteristics on the axial strength of such bonds. Several geometries were tested by loading a total of 190 specimens to failure.

The ultimate load values found for the specimens were compared to the design values proposed in the final draft version of Eurocode 5 (prEN 1995-1-1(2001)).

Keywords: glued joints, joint design, adhesives for wood, destructive testing, hardwood timber.
(*) Universidad de A Coruña (A Coruña, España).

Persona de contacto/Corresponding author: marilo@udc.es 


\section{INTRODUCCIÓN}

Las barras encoladas en madera se utilizan en los países escandinavos y Alemania desde la década de los '70.

El campo de aplicación inicial de los vástagos encolados era el de la prevención de hendiduras en las zonas de cumbrera de vigas curvas y en huecos o entalladuras de elementos de madera laminada, derivando posteriormente a su uso como uniones estructurales en obras de nueva planta, especialmente en la base de pilares y en uniones en ángulo y embrochaladas.

Desde los años '80 se han realizado diversos estudios experimentales con el objetivo de formular la capacidad de carga de estas uniones, en función de los parámetros geométricos que intervienen en su diseño y de las características de los materiales utilizados. No obstante, estos análisis experimentales se circunscriben fundamentalmente al campo de la madera laminada encolada. En el ámbito normativo contamos con una propuesta de diseño incluida a modo de Anexo Informativo en el Eurocódigo 5 (1), en su versión de borrador final prEN 1995-1-1 (2001), recomendada también únicamente para su aplicación en elementos de madera laminada. Estudios experimentales previos realizados por nuestro equipo de investigación (2) han puesto de manifiesto discrepancias importantes entre los valores de cálculo proporcionados por estas fórmulas y los valores experimentales obtenidos cuando se utiliza madera de frondosa de densidad elevada. Esto nos ha llevado a realizar una campaña experimental más amplia con el objeto de evaluar la relación entre las propiedades de la madera y la capacidad de carga de las uniones, cuyos resultados se resumen en el presente artículo.

\section{DESCRIPCIÓN DE LOS ENSAYOS REALIZADOS}

\subsection{Materiales}

Con objeto de evaluar la influencia de las características de la madera en la capacidad resistente de la unión, se realizaron probetas utilizando madera de castaño (Castanea sativa Mill.) y de elondo o tali (Erythrophleum ivorense A. Chef.); dos especies de maderas frondosas de propiedades físicas y mecánicas muy diferentes. La primera se seleccionó atendiendo al enorme potencial que las uniones encoladas ofrecen en el ámbito de la restauración y rehabilitación de edificios históricos, puesto que éste representa, en nuestro país, su uso actual más prometedor. Considerando este aspecto se planteó el uso de una especie de

\section{INTRODUCTION}

Steel bars have been glued to wood in the Scandinavian countries and Germany since the nineteen seventies.

While glued-in rods were initially devised to prevent cleavage at the ridges of curved beams and around openings or carvings in laminated wood members, their use was later extended to structural bonds in new works, especially for column bases, angle joints and trimmer joists.

Studies have been conducted since the nineteen eighties to determine how the load strength of these bonds is affected by their geometric design and the characteristics of the materials used. These experiments, however, have been limited essentially to glued laminated timber. The informative annex to Eurocode 5 (1) (final draft version, prEN 1995-1-1(2001)) contains a design proposal for glued joints, likewise recommended for use only in laminated timber elements. Prior research (2) revealed substantial discrepancies between the design values found with these formulas and the experimental values obtained for high density hardwood. This led to a broader experimental campaign aimed at evaluating the relationship between wood properties and bond load capacity, whose findings are summarized in the present article.

\section{TESTS}

\subsection{Materials}

Specimens made from two hardwood species, chestnut (Castanea sativa Mill.) and tali (Erythrophleum ivorense A. Chef.), with very different physical and mechanical properties were tested to evaluate the effect of wood characteristics on joint axial strength.The first was selected because of the enormous potential for glued joints in the restoration and rehabilitation of historic buildings, the most promising use of such bonds in Spain today. The species chosen has been traditionally used in construction in Galicia, a region in north-western Spain. The second is a tropical hardwood that is sufficiently dense, in ample supply and widely used across the 
madera de frondosa tradicionalmente utilizada para la construcción en Galicia. La segunda de las especies se corresponde con una madera tropical que cumple los requisitos de densidad elevada y disponibilidad. Se trata de una especie de uso extendido en nuestro país y que cuenta además con una fibra muy entrelazada, que permitió obtener piezas prácticamente libres de defectos, a excepción de ligeras fendas de secado en algunos ejemplares.

Cada ejemplar fue medido y pesado, de acuerdo con la norma UNE 56531-77 (3), para determinar su peso específico. Los valores de peso específico obtenidos fueron un valor medio de $561,5 \mathrm{~kg} / \mathrm{m}^{3}$ (con un valor característico del $5^{\circ}$ percentil de $\left.469,5 \mathrm{~kg} / \mathrm{m}^{3}\right)$ para el castaño y un valor medio de $867,5 \mathrm{~kg} / \mathrm{m}^{3}$ (con un valor característico del $5^{\circ}$ percentil de $796,2 \mathrm{~kg} / \mathrm{m}^{3}$ ) para el elondo. La determinación del contenido de humedad de las probetas se efectuó a partir de los bloques de madera de cada probeta, realizando medidas en cada cara con un xilohigrómetro digital de púas (Protimeter TimberMaster) previamente a la realización de los taladros para alojar las barras. Este sistema de medida utilizado obedecía a que la forma de rotura de las probetas, así como el encolado, dificultaba la extracción de una rebanada de sección completa con posterioridad a la realización de los ensayos. Al mismo tiempo, esto permitía establecer el valor de densidad de la madera previamente a la realización de los ensayos, lo que posibilitaba aplicar las fórmulas del Eurocódigo para realizar un predimensionado previo.

Debido a la inexistencia de madera clasificada de estas especies de frondosa, se procedió a un registro exhaustivo de los defectos de las piezas para evaluar su posible repercusión en el fallo de las uniones. En el caso de las probetas de elondo los defectos se reducían a pequeñas fendas de secado. En las probetas de castaño existían además piezas con nudos sanos.

Tras los ensayos se constató que los defectos puntuales existentes en la madera, principalmente pequeños nudos y fendas, no precipitaron en ningún caso el fallo de las probetas. Tampoco se encontró relación alguna entre el desarrollo de las fracturas en las piezas de madera (cuando el fallo se producía por hienda o por rotura por cortante de la madera) y la presencia de estos defectos locales. Las Figuras $1 \mathrm{a}$ y $1 \mathrm{~b}$ ilustran significativamente esta falta de incidencia de los defectos de la madera en el modo de rotura de las probetas.

Para la selección del adhesivo se realizó una campaña experimental previa en la que se evaluaron un total de 7 adhesivos diferentes (4), dentro de una selección de adhesivos estructurales recomendados para su aplicación tanto en madera como en acero, entre los que se encontraban diversos tipos de resinas con base epoxídica y epoxi-acrilato, y country. Its intertwined fibres ensured practically flawless specimens, with the exception of slight drying fissures in a few samples.

Each specimen was measured and weighed as specified in Spanish standard UNE 56531-77 (3) to determine its density. The mean density found for chestnut was 561.5 $\mathrm{kg} / \mathrm{m}^{3}$ (with a characteristic (fifth percentile) value of $469.5 \mathrm{~kg} / \mathrm{m}^{3}$ ) and for tali wood, $867.5 \mathrm{~kg} / \mathrm{m}^{3}$ (with a characteristic (fifth percentile) value of $796.2 \mathrm{~kg} / \mathrm{m}^{3}$ ). The moisture content of the specimens was determined with blocks of wood from each. Measurements were taken on all six sides of the samples with a Protimeter TimberMaster digital moisture meter prior to drilling the holes in the specimens to house the bars. This procedure was used because intact slices of wood were difficult to extract after testing, due to the specimen failure mode and the holes drilled into the specimens to embed the bars. The wood density values could also be found with these same samples prior to testing, making it possible to use the Eurocode formulas for predimensioning.

In the absence of classified wood for these species, an exhaustive record was made of the flaws in the specimens to evaluate their possible impact on bond failure. In the tali wood, the flaws were limited to small drying fissures, while some of the chestnut specimens had healthy knots as well as fissures.

The test findings showed that these occasional flaws in the wood, primarily small knots and fissures, did not precipitate specimen failure in any of the cases studied. Nor was any relationship found between fracture development (in the event of cleavage- or shear-induced failure) and the presence of such local flaws. Figures 1 a and $1 b$ clearly show that they had no impact on specimen failure mode.

Preliminary experiments were conducted to choose the adhesive. A total of seven of the adhesives (4) recommended for use with wood and steel were assessed, including several types of epoxy or epoxyacrylate resins and polyurethane, polyester and neoprene glues. Since the best results were found with 
adhesivos de poliuretano, poliéster y neopreno. Dentro de ellos los adhesivos epoxi bicomponente fueron los que proporcionaron mejores resultados, por lo que éste fue el sistema de adhesivo utilizado en la campaña de ensayos definitiva. Éste era también el adhesivo que poseía unas cualidades físicas más adecuadas para la ejecución de las probetas, puesto que contaba con una fluidez adecuada que facilitaba su distribución homogénea a lo largo de toda la longitud de anclaje. El adhesivo utilizado, constituido por dos componentes: resina de base epoxídica bisfenol A/F con relleno inorgánico y poliamida alifática con relleno inorgánico, se comercializa en cartuchos que posibilitan el mezclado automático en el momento de la inyección en los taladros, garantizando la proporción correcta de los dos componentes.

Como elemento de enlace se utilizaron barras roscadas de acero galvanizado de alta resistencia. El acero era de calidad 8.8 en el caso de las probetas de castaño y 12.9 en el caso de las probetas de elondo, puesto que las cargas de rotura esperadas en estas probetas eran superiores. Se utilizaron aceros de alta resistencia con el objetivo de garantizar que el fallo no estuviese determinado en ningún caso por la rotura de las barras de acero.

\subsection{Configuración geométrica}

Se diseñaron probetas con dos uniones idénticas en los extremos, con el objetivo de realizar ensayos de tracción doble.

En relación con la configuración geométrica de las probetas, existen cuatro parámetros considerados básicos dentro del diseño de las uniones: la longitud de anclaje, el diámetro de la barra, el espesor del adhesivo y las dimensiones del elemento de madera. El estudio del estado del arte correspondiente a uniones encoladas sometidas a solicitación axil, así como nuestros estudios experimentales previos, nos permitieron fijar algunos de estos parámetros, para poder centrar el análisis experimental sobre aquellos respecto a los cuales no existen conclusiones definitivas.

Respecto a las dimensiones de la sección de la pieza de madera, los estudios existentes (5-6) coincidían en señalar que dimensiones muy reducidas podían precipitar el fallo de las uniones por la hienda de la madera. Para prevenir este fallo se fijó una distancia al borde de 3 veces el diámetro de la barra, superior a las recomendaciones del Eurocódigo 5 al respecto y a las de la mayoría de los autores consultados $(5,7-8)$. En la misma línea, se fijó una separación intermedia entre los extremos interiores de las barras igual a la longitud de anclaje, considerándose (9) que ésta es una distancia suficiente para que se uniformice la distribución de tensiones normales en la sección transversal de la pieza de madera. two-component epoxy adhesives, this was the type used in the final tests. In addition, the flowability of this adhesive, which facilitated an even spread along the entire anchorage length, also made it particularly well suited to preparing the specimens. It is sold in cartridges that automatically mix the two components, a bisphenol $A / F$ epoxy resin with inorganic filler and an aliphatic polyamide with inorganic filler, in the right proportions as the product is injected into the drill holes.

High strength, galvanized threaded steel bars were chosen as the bonding elements. For the chestnut specimens, 8.8 quality steel was used, while 12.9 quality was needed for the tali wood joints, which were expected to withstand greater ultimate loads. High strength steel was used to guarantee that failure would not be attributable to bar rupture.

\subsection{Geometry}

The specimens were designed with two identical joints at each end to conduct double punch tests for tensile strength.

Joint geometry was regarded to be essentially defined by four parameters: anchorage length, bar diameter, thickness of the layer of adhesive and size of the wood element. Since some of these parameters could be optimized based on the preliminary tests described above and state of the art literature respecting axially stressed glued bonds, the present experimental analysis focused on the parameters for which no conclusive findings are available.

It is generally agreed (5-6) that small size specimens may precipitate bond failure due to wood cleavage. To prevent this type of failure, the distance of the bar from the edge was set at three times its diameter, which is more than specified in Eurocode 5 or reported by most of the authors consulted (5, 7-8). In this same vein, the inner ends of the bars were spaced at an interval ( $\mathrm{Li}$ in Table 1) equal to the anchorage length, since this distance was assumed to suffice (9) to ensure the even distribution of normal stresses in the cross-section of the specimen. 
El espesor de adhesivo se fijó en $1 \mathrm{~mm}$. Esto respondía a las recomendaciones normativas relativas al uso de líneas de encolado delgadas y era un valor que se encontraba también dentro del rango recomendado por los fabricantes del adhesivo. Experiencias previas (2) nos habían demostrado que el volumen excesivo de adhesivo necesario para la realización de líneas de encolado más gruesas no se ve recompensado con valores de carga de rotura proporcionalmente mayores.

Los parámetros variados fueron la longitud de anclaje y el diámetro de las barras. Se utilizaron barras de 10 y 12 mm, pues éstos eran valores tradicionalmente utilizados en ensayos similares, posibilitando comparaciones posteriores.

Se ensayaron cinco longitudes de encolado diferentes, cubriendo un rango desde los $60 \mathrm{~mm}$ hasta los $180 \mathrm{~mm}$.

Con la combinación de estos parámetros se obtuvieron 10 tipos de probetas con características geométricas diferentes que se repitieron para cada especie de madera. Sus características se resumen en la Tabla 1.
The thickness of the layer of adhesive was one $\mathrm{mm}$. This was both in keeping with standard recommendations on the use of thin layers of glue and within the range recommended by the adhesive manufacturers. Prior studies (2) showed that the extra volume of adhesive needed for thicker layers of glue was not offset by proportionally higher ultimate load values.

The variables used were anchorage length and bar diameter. Ten- and 12- $\mathrm{mm} \varnothing$ bars were chosen to facilitate subsequent comparison, for these are the sizes conventionally used in such tests.

Five glued anchorage lengths were tested, ranging from 60 to $180 \mathrm{~mm}$.

The combination of these two parameters yielded 10 specimen geometries for each wood species, as summarized in Table 1.

Tabla 1 / Table 1

Características geométricas de las probetas ensayadas (en $\mathrm{mm}$ ). Specimen geometry (in $\mathrm{mm}$ ).

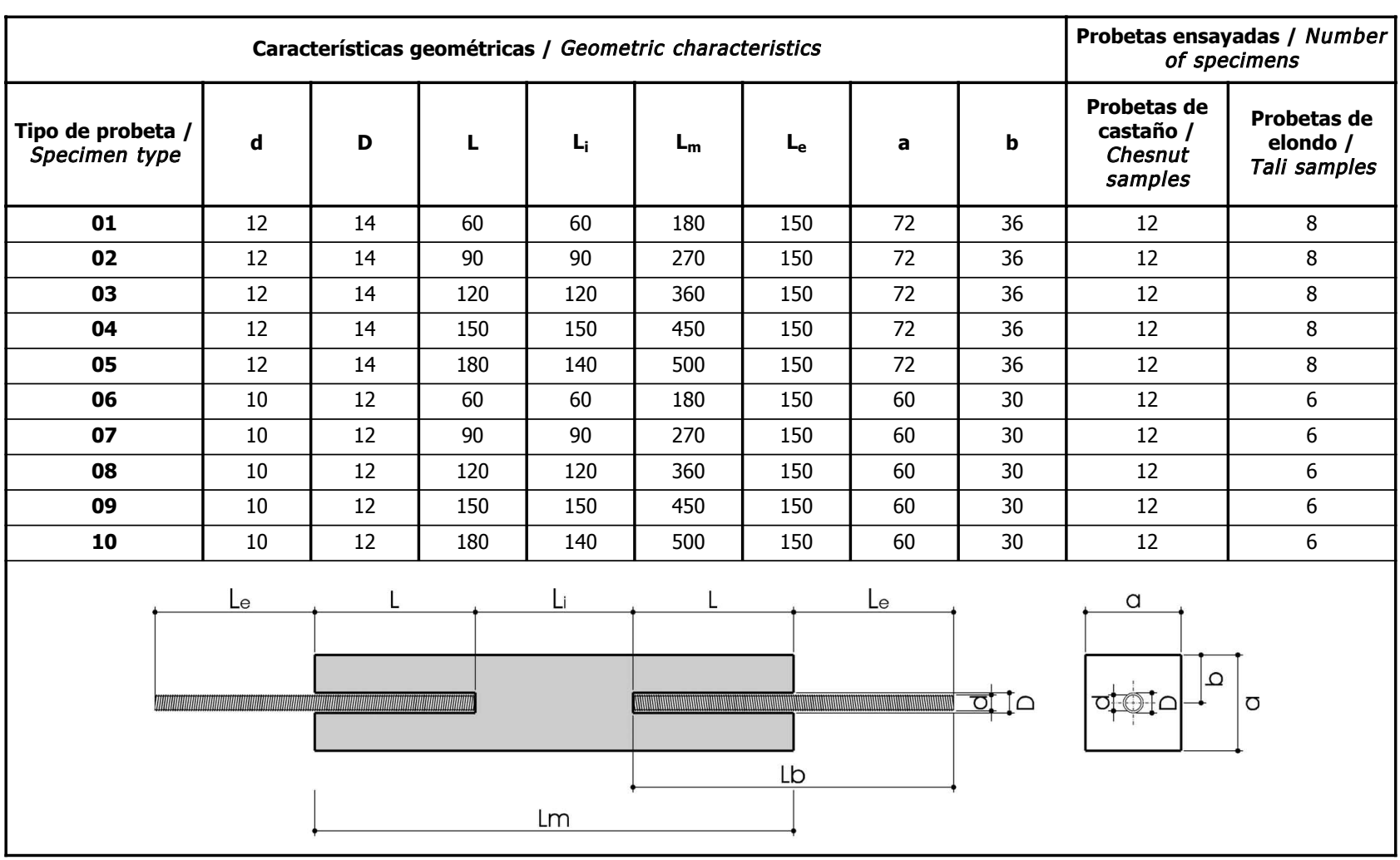

\subsection{Dispositivo de ensayo}

No existe normativa específica para el ensayo de uniones realizadas con barras encoladas en madera.

\subsection{Test apparatus}

No specific legislation is in place for testing the bonds formed by gluing steel bars to wood. 
Las probetas se ensayaron hasta rotura en una prensa universal con capacidad para $1.000 \mathrm{kN}$. La carga se aplicó por desplazamiento constante, ajustando en cada caso la velocidad para que la rotura se produjese dentro de los $5 \pm 2$ minutos establecidos como duración de los ensayos de corta duración para la determinación de propiedades mecánicas de la madera (UNE-EN 408) (10). Se utilizó un cilindro intermedio entre las barras de acero y las mordazas, para que la transmisión de la carga no introdujese flexiones en las probetas.

\section{RESULTADOS Y DISCUSIÓN}

En la Tabla 2 se resumen los valores medio y característico ( $5^{\circ}$ percentil) de las cargas de rotura obtenidas para cada tipo de probeta. La determinación del valor característico de la carga de rotura en cada tipo de probetas, se ha realizado de acuerdo con el CTE DB-SE, capítulo 5 (11). A pesar de que el número total de ensayos realizados es de 190 , el valor característico puede no considerarse representativo dentro de cada tipo de probeta, debido al número de ejemplares ensayados. Por ese motivo se indica también el valor mínimo de carga de rotura para cada tipo de probeta. No obstante, es importante destacar que el objetivo de los ensayos no era determinar valores de resistencia de las uniones, sino evaluar comparativamente los resultados de probetas con características geométricas distintas y la adecuación de la propuesta del Eurocódigo 5 para su uso en uniones realizadas en madera de frondosa de distintas características y densidades.

En la Tabla 2 se incluyen también los valores de resistencia de la unión proporcionados por el Eurocódigo 5. Estos valores constituyen una referencia útil como patrón para evaluar la incidencia de los distintos parámetros, geométricos y materiales, en la capacidad de la unión; dado que el Código Técnico de la Edificación no ha incluido criterios de cálculo para el diseño de este tipo de uniones, el Eurocódigo 5 constituye la principal referencia normativa con la que contamos para el diseño de las uniones encoladas en madera, a pesar de tratarse de una propuesta considerada únicamente a modo de borrador y que no ha sido incluida en posteriores versiones. Esta versión del Eurocódigo recomienda las siguientes expresiones para determinar la capacidad de las uniones encoladas realizadas en madera laminada:
The present specimens were tested to failure in a 1000$k N$ universal test frame. The specimens were loaded under continuous pressure at speeds that would ensure failure within the 5+2-minute duration for short-term mechanical tests in wood specified in Spanish and European standard UNE-EN 408 (10). A cylinder was positioned between the steel bars and the clamps to prevent load transmission from generating flexural stress in the specimens.

\section{RESULTS AND DISCUSSION}

Table 2 summarizes the mean and characteristic (5th percentile) ultimate load values found for each type of specimen. The characteristic ultimate load value was found as specified in the Spanish Technical Building Code (CTE DB-SE), chapter 5 (11). Despite the fairly large number of tests conducted, 190 in all, the characteristic value for each specimen type may not be fully representative due to the short number of samples tested. The minimum ultimate load is also shown for each specimen type for this reason. Nonetheless, the purpose of the tests was not to determine bond strength, but rather to compare the results for specimens with different geometries and the suitability of the Eurocode 5 proposal for bonds in hardwood of different characteristics and densities.

Table 2 also gives the joint strength values furnished in Eurocode 5. These values constitute a useful reference for evaluating the impact of the parameters, geometries and materials tested on bond strength. Since the Spanish Technical Building Code contains no engineering design criteria for this type of bonds, the aforementioned version of Eurocode 5 is the country's chief regulatory reference for glued wood joints, even though the proposal is set out in a draft version only and was dropped from subsequent editions of the code. The recommendations contained in the said version of the Eurocode to determine the strength of glued bonds in laminated timber were as follows:

$$
\begin{gathered}
R_{a x, k}=\pi \cdot d_{e q u} \cdot L_{g} \cdot f_{v a k} \\
f_{v a k}=f_{v 90 k} /\left(\sin ^{2} \alpha+1,5 \cdot \cos ^{2} \alpha\right) \\
f_{v 90 k}=1,2 \cdot 10^{-3} \cdot \rho_{k}^{1,5} \cdot d_{\text {equ }}^{-0,2}
\end{gathered}
$$


$\mathrm{R}_{\mathrm{ax}, \mathrm{k}}$ Carga axial característica (N).

$\mathrm{f}_{\mathrm{vak}}$ Resistencia a la extracción $\left(\mathrm{N} / \mathrm{mm}^{2}\right)$ para un taladro realizado con un $\alpha$ ángulo respecto a la dirección de la fibra de la madera.

d Diámetro del agujero $(\mathrm{mm})$.

$\mathrm{d}_{\text {equ }}$ El menor de: diámetro del agujero $(\mathrm{mm})$ y 1,25 veces el diámetro de la barra $(\mathrm{mm})$.

$\mathrm{L}_{\mathrm{g}} \quad$ Longitud de anclaje $(\mathrm{mm})$.

$\rho_{\mathrm{k}} \quad$ Densidad característica de la madera $\left(\mathrm{kg} / \mathrm{m}^{3}\right)$.

Los valores calculados a partir de estas expresiones, utilizando para cada tipo de madera el valor de densidad característica correspondiente, se resumen en la Tabla 2 y se representan gráficamente en la Figura 2, comparándolos con los valores obtenidos experimentalmente.
$R_{a x, k}$ Characteristic axial load (N).

$f_{\text {vak }}$ Withdrawal strength $\left(\mathrm{N} / \mathrm{mm}^{2}\right)$ for a hole drilled with an angle $\alpha$ respect to grain direction.

d Hole diameter ( $\mathrm{mm}$ ).

$d_{\text {equ }}$ Lowest of: hole diameter $(\mathrm{mm})$ and 1.25 times the diameter of the bar $(\mathrm{mm})$.

$L_{g} \quad$ Glued-in anchorage length $(\mathrm{mm})$.

$\rho_{\mathrm{k}} \quad$ Timber characteristic density $\left(\mathrm{kg} / \mathrm{m}^{3}\right)$.

The values calculated from the above expressions and the characteristic density for each type of wood are summarized in Table 2 and compared to the experimental values in the graph in Figure 2.

Tabla 2 / Table 2

Cargas de rotura obtenidas experimentalmente y valores calculados a partir de la propuesta del Eurocódigo 5 (en kN). Ultimate load values for steel-hardwood joints, empirical and calculated as specified in Eurocode 5 (in $\mathrm{kN}$ ).

\begin{tabular}{|c|c|c|c|c|c|c|c|c|}
\hline \multirow[b]{2}{*}{$\begin{array}{l}\text { Tipo de } \\
\text { probeta / } \\
\text { Specimen } \\
\text { type }\end{array}$} & \multicolumn{4}{|c|}{$\begin{array}{c}\text { Resultados para probetas de castaño. Cargas de rotura / } \\
\text { Results of chestnut specimens. Failure loads }\end{array}$} & \multicolumn{4}{|c|}{$\begin{array}{c}\text { Resultados para probetas de elondo. Cargas de rotura / } \\
\text { Results of tali specimens. Failure loads }\end{array}$} \\
\hline & $\begin{array}{c}\text { Valor medio / } \\
\text { Mean value }\end{array}$ & $\begin{array}{c}\text { Valor mínimo } \\
\text { / Mínimum } \\
\text { value }\end{array}$ & $\begin{array}{c}\text { Valor } \\
\text { característico } \\
\mathbf{5}^{\circ} \text { percentil / } \\
\text { Characteristic } \\
\text { value }\end{array}$ & $\begin{array}{c}\text { Propuesta del } \\
\text { Eurocódigo } 5 \text { / } \\
\text { Eurocode } 5 \\
\text { proposal }\end{array}$ & $\begin{array}{c}\text { Valor medio / } \\
\text { Mean value }\end{array}$ & $\mid \begin{array}{c}\text { Valor mínimo / } \\
\text { Mínimum } \\
\text { value }\end{array}$ & \begin{tabular}{|c|} 
Valor \\
característico \\
$\mathbf{5}^{\circ}$ percentil / \\
Characteristic \\
value
\end{tabular} & $\begin{array}{c}\text { Propuesta del } \\
\text { Eurocódigo } 5 \text { / } \\
\text { Eurocode } 5 \\
\text { proposal }\end{array}$ \\
\hline 01 & 27.09 & 19.61 & 13.14 & 12.89 & 27.72 & 24.28 & 20.77 & 28.18 \\
\hline 02 & 41.26 & 32.17 & 28.05 & 19.34 & 43.78 & 39.24 & 36.67 & 42.27 \\
\hline 03 & 45.92 & 39.93 & 36.63 & 25.78 & 57.53 & 53.15 & 47.84 & 56.36 \\
\hline 04 & 47.67 & 32.35 & 34.74 & 32.23 & 80.35 & 70.87 & 70.58 & 70.45 \\
\hline 05 & 49.44 & 43.26 & 40.28 & 38.68 & 82.56 & 77.16 & 74.95 & 84.54 \\
\hline 06 & 23.20 & 16.84 & 13.13 & 11.40 & 22.75 & 19.54 & 16.73 & 24.91 \\
\hline 07 & 30.12 & 22.21 & 19.13 & 17.09 & 39.87 & 35.76 & 32.31 & 37.36 \\
\hline 08 & 35.85 & 26.29 & 25.66 & 22.79 & 48.93 & 39.82 & 34.17 & 49.82 \\
\hline 09 & 36.25 & 28.84 & 28.23 & 28.49 & 54.63 & 45.03 & 41.28 & 62.27 \\
\hline 10 & 38.49 & 35.88 & 30.66 & 34.19 & 52.44 & 42.38 & 34.48 & 74.73 \\
\hline
\end{tabular}

\subsection{Modos de rotura}

El fallo de las uniones encoladas puede estar condicionado por cualquiera de los tres materiales que intervienen en su diseño: el adhesivo, la madera y el acero. En la práctica, puede ser recomendable diseñar uniones condicionadas por el fallo de las barras de acero, para obtener roturas de tipo dúctil. No obstante, en el análisis experimental de las uniones se diseñan probetas en las que el fallo esté determinado por la capacidad máxima de la unión madera-adhesivo, para establecer la resistencia asociada a esta superficie crítica. De este modo, los fallos más habituales son el fallo por hienda de la madera y el fallo por cortante en la superficie próxima a la línea de encolado, poniendo de manifiesto que se trata de un fallo por cortante en la madera mediante el arranque de fibras $y / 0$ un bloque de madera.

\subsection{Failure modes}

Failure in glued joints may be conditioned by any one of the three materials involved: adhesive, wood or steel. In practice, it may be recommendable to design bonds limited by the strength of the steel to ensure ductile failure. Nonetheless, in the present experimental analysis specimens were designed to fail when the maximum capacity of the wood-adhesive bond was exceeded, with a view to establishing the strength associated with that critical surface. Under these conditions, wood cleavage and shear failure near the surface adhered to the glue were the most common types of failure, i.e., due to shear stress on the wood leading to detachment of fragments and/or whole blocks of wood. 


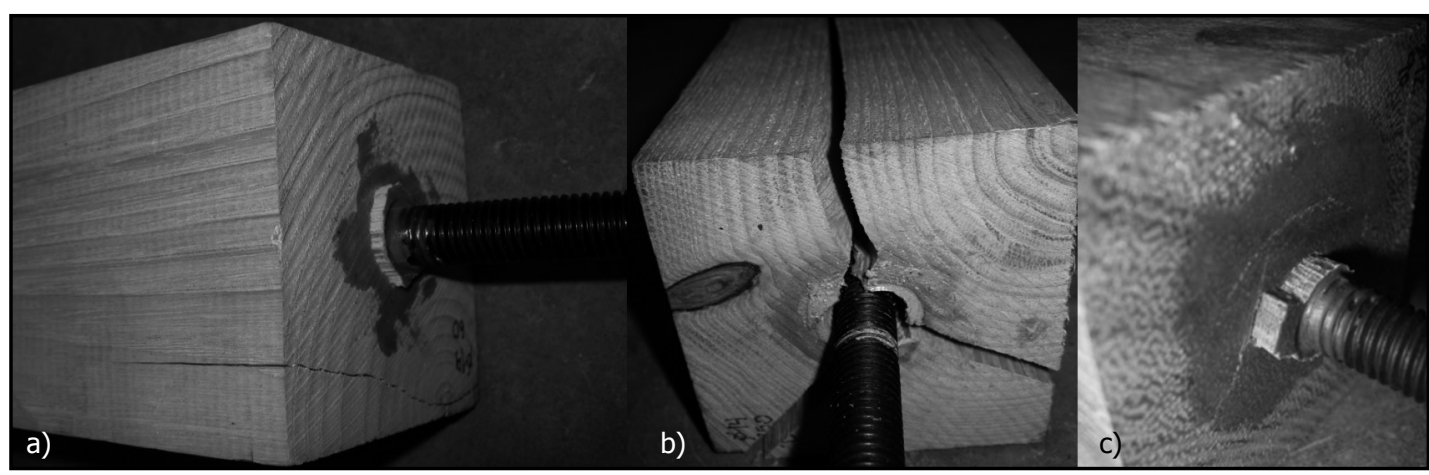

Figura 1. Ejemplos de los modos de rotura más habituales. (a) Rotura por corte en la superficie madera-adhesivo para probetas de castaño, independiente de la fenda existente en la pieza de madera. (b) Rotura por hendidura de la madera en probetas de castaño, independiente del nudo existente en la pieza de madera. (c) Rotura por corte en la superficie madera-adhesivo para probetas de elondo.

Figure 1. Examples of the most common failure modes. (a) Shear failure at the wood-adhesive surface in chestnut specimens, regardless of cleavage in the wood. (b) Cleavaje-induced failure in chestnut specimens, irrespective of the knot in the sample. (c). Shear failure at the wood-adhesive surface in tali wood specimens.

En las probetas realizadas con madera de castaño (120 en total) se produjeron diversos tipos de fallos. El mayoritario era el fallo por cortante en la madera $(67,2 \%)$. Este fallo se evidenciaba por la extracción de un bloque de madera adherido a la barra (Figura 1a). En algunos casos el fallo se producía coincidiendo con la línea de encolado, evidenciándose en ese caso el fallo por corte en la presencia de fibras de madera adheridas al bloque de adhesivo. En otros casos el fallo se produjo por hienda de la madera (14,4\%) (Figura 1b), rotura de la barra de acero $(14,4 \%)$ u otros motivos (4\%) como podían ser el fallo del adhesivo o el fallo en los resaltes de la barra roscada. En las probetas de elondo, el fallo se produjo en todos los casos por cortante en la superficie maderaadhesivo (Figura 1c). Esta diferencia podía deberse a la mayor homogeneidad de la madera utilizada para las probetas de elondo o a la elevada resistencia de esta especie.

En las probetas de castaño, se comprobó que los diversos modos de rotura no tenían incidencia en los valores de rotura, puesto que probetas con las mismas características geométricas y distintos modos de rotura alcanzaban valores de carga equiparables. Se comprobó asimismo que los defectos de la madera (nudos sanos y pequeñas fendas registrados en la fase previa) no afectaban tampoco a los valores de rotura alcanzados ni guardaban relación en ningún caso con el trazado o el modo de fallo de las piezas. Ejemplos de esta ausencia de relación pueden verse en las Figuras 1a y 1b.

\subsection{Influencia de los parámetros geométricos}

La mayoría de las propuestas de cálculo de la resistencia a solicitación axial para uniones encoladas en madera establecen una relación lineal entre la capacidad de carga de la unión y los parámetros geométricos de longitud de anclaje y diámetro de las barras $(1,5,7)$, puesto que
Several types of failure were recorded in the 120 specimens made with chestnut wood. The most common (67.2\%) was shear failure in the wood. In this type of failure the bar pulled out of the specimen, drawing part of the wood with it (Figure 1a). In some samples exhibiting shear failure the fault concurred with the layer of resin, which tore fragments off the wood as it pulled away from the specimen. In others $(14.4 \%)$ the wood cleaved (Figure $1 b)$, the bar broke $(14.4 \%)$ or failure was caused by other factors (4\%), such as failure of the adhesive or the thread on the bar. Shear failure at the wood-adhesive surface (Figure 1c) was observed in all the tali wood specimens. This difference in failure mode may be due to the greater homogeneity of the wood used to make the tali specimens or to the high strength of this material.

The failure mode was found to have no effect on chestnut wood failure values, for specimens with the same geometries and different failure modes reached comparable ultimate load values. The flaws in the wood (healthy knots and small fissures observed in the preliminary phase) were likewise found to have no effect on the failure values, or to bear any relationship to the failure pattern or mode (see Figures $1 \mathrm{a}$ and $1 \mathrm{~b}$.).

\subsection{Effect of geometry}

Most of the proposals for calculating axial strength in glued wood joints establish a linear relationship between bond load capacity and the two geometric parameters, anchorage length and bar diameter $(1,5,7)$, that define the critical surface where failure occurs. Figure 2 shows 
estos dos parámetros definen la superficie crítica en la que se produce en fallo. En la Figura 2 se han representado los valores de carga de rotura obtenidos experimentalmente para probetas realizadas con barras de $10 \mathrm{~mm}$. Los puntos representan probetas realizadas en madera de castaño y las aspas probetas de elondo. Las líneas discontinuas unen los valores medios de carga de rotura para cada tipo de probeta. En ambos casos puede apreciarse claramente la divergencia respecto de la relación lineal entre la capacidad de carga de la unión y su longitud de anclaje propuesta por el Eurocódigo y otras fórmulas de cálculo, y los valores obtenidos experimentalmente, especialmente en el caso de uniones más largas. La imagen pone también de manifiesto que la incidencia de las características de la madera varía con la longitud de anclaje de la unión, puesto que los valores medios obtenidos para ambas maderas en las uniones más cortas son prácticamente coincidentes. Asimismo, la Figura 2 evidencia que la propuesta del Eurocódigo no es de aplicación para maderas de densidad elevada, puesto que los resultados obtenidos experimentalmente para el elondo son inferiores a los valores teóricos en el $60 \%$ de las probetas. Este valor alcanza el $100 \%$ en las longitudes más elevadas. El comportamiento descrito se repite en el caso de las probetas realizadas con barras de $12 \mathrm{~mm}$.

Observando los valores resumidos en la Tabla 2 puede concluirse lo mismo respecto al diámetro de las barras. Al aumentar el diámetro de las barras de 10 a 12 mm, se produce un incremento del $16 \%$ en la superficie de encolado. the experimental ultimate load values for specimens with glued-in 10-mm bars. The dots represent chestnut and the X's tali wood specimens. The dashes join the mean ultimate load values for each specimen type by wood species. The linear relationship between bond load capacity and anchorage length proposed by the Eurocode and other design formulas was observed to diverge clearly from the experimental values, particularly in the case of the longer bonds. As the graph shows, the impact of wood characteristics varied with bond anchorage length, given that the mean values obtained for the shortest bonds were practically the same in the two wood species. Figure 2 also shows that the Eurocode proposal is not applicable to high density wood, for the experimental findings for tali wood were lower than the theoretical values in $60 \%$ of the specimens, and in $100 \%$ of the specimens with long anchorages. The same pattern was observed in specimens wit 12-mm bars.
Further to the values in Table 2, the same conclusion can be drawn with respect to the bar diameter. When the diameter was increased from 10 to $12 \mathrm{~mm}$, the anchorage was lengthened by $16 \%$. A review of the

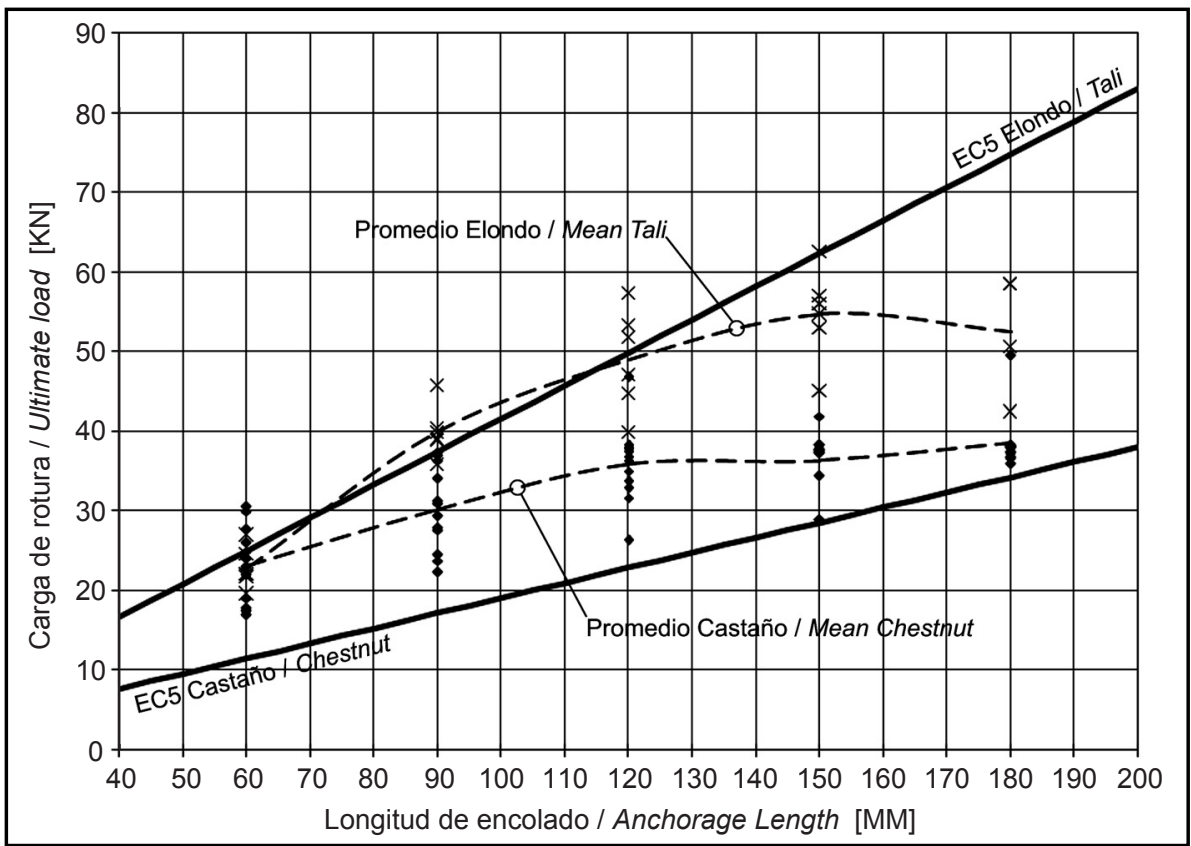

Figura 2. Valores de carga de rotura obtenidos experimentalmente para elondo (representados con aspas) y para castaño (representados con puntos), correspondientes a probetas realizadas con barras de $10 \mathrm{~mm}$ de diámetro (tipos 6 a 10). Las líneas continuas representan los valores obtenidos a partir de la propuesta de diseño incluida en el Eurocódigo 5 (eq. 1-3) para cada una de las especies de madera.

Las líneas discontinuas unen los valores medios de rotura obtenidos para cada tipo de probeta y cada especie.

Figure 2. Experimental ultimate load values for tali wood $(X ' s)$ and chestnut (dots) specimens with 10-mm diameter bars (types 6 through 10). The solid lines represent the values obtained using the Eurocode 5 design proposal (Equations 1-3). The dashes join the mean failure values obtained for each specimen type by wood species. 
Comparando los valores medios de carga de rotura obtenidos para cada tipo de probeta, se observa que no existe una relación constante entre los valores obtenidos por probetas con la misma longitud de anclaje y distinto diámetro de la barra. Si bien en algunos tipos de las probetas realizadas con castaño (1-6/5-10) el incremento de carga obtenido es aproximadamente el esperado, aprox. 16\%; en los restantes el incremento es muy variable, desde el $20 \%$ hasta el $60 \%$.

Este comportamiento avala la llamada Teoría de Volkersen (12), según la cual la resistencia de la unión está relacionada con las tensiones de corte que se producen en la línea de encolado, que serían casi uniformes en uniones cortas y que alcanzarían picos elevados en los extremos a medida que las uniones se alargan; lo que redunda en tensiones de corte medias más reducidas en las uniones más largas.

\subsection{Influencia de la densidad y la resistencia de la madera}

Muchas de las propuestas de diseño incluyen también entre los parámetros de cálculo el valor de la densidad de la madera (1-7-13). A este respecto, la propuesta del Eurocódigo 5 considera incluso una incidencia exponencial de este parámetro en la resistencia de la unión. La relación entre ambos parámetros, densidad y resistencia, es evidente en la caracterización resistente de las distintas especies de madera; pero no existen estudios experimentales que avalen su relación con la capacidad de carga de las uniones encoladas.

Para evaluar la incidencia de este parámetro en la capacidad resistente de la unión se realizó una primera comparación con los valores de rotura obtenidos para cada tipo de probeta diferenciando la especie de madera utilizada. Los valores de peso específico aparente obtenidos para cada una de las probetas ensayadas oscilaban entre 433,6 y $690,5 \mathrm{~kg} / \mathrm{m}^{3}$ en el caso de las probetas de castaño (lo que supone un incremento próximo al $60 \%$ entre el máximo y el mínimo) y entre 747,4 y $986,9 \mathrm{~kg} / \mathrm{m}^{3}$ para el elondo (lo que supone un incremento próximo al $30 \%$ entre el máximo y el mínimo). Esta variación debería verse reflejada, en primer término, entre las probetas del mismo tipo realizadas con la misma especie de madera. Para ello, se ha realizado para cada tipo de probeta, una comparación entre los valores de rotura alcanzados por cada ejemplar y el valor de densidad de la pieza de madera correspondiente a dicha probeta. A modo representativo, la Figura 3 muestra un ejemplo de la comparación efectuada para los resultados de carga de rotura obtenida para los diferentes ejemplares de las probetas de tipo 5 realizadas con madera de castaño; resultados similares se obtuvieron en la gráficas comparativas realizadas para los restantes tipos de probetas y para las dos especies de madera utilizadas. La comparación muestra que no existe ninguna relación aparente entre mean ultimate load values revealed no consistent relationship between specimens with the same anchorage length but a different bar diameter. While in some types of chestnut specimens (1-6/5-10), the increase was as expected, i.e., approximately $16 \%$, in all the others the rise was variable, from 20 to $60 \%$.

Such behaviour endorses the so-called Volkersen theory (12), according to which bond strength is related to the shear stress generated on the adhesive, which would be nearly uniform in short bonds, but would rise sharply on the two ends with rising anchorage length. This results in smaller mean shear stress in longer bonds.

\subsection{Effect of wood density and strength}

Many of the design proposals (1-7-13) also include wood density as a design parameter. The Eurocode 5 proposal, in fact, even assumes that density has an exponential effect on bond strength. While the relationship between density and strength is obvious from the characteristic strength values for different species of wood, such a relationship between density and the load capacity of glued joints has yet to be corroborated by experiment.

To evaluate the effect of density on bond axial strength, the ultimate load values obtained for each type of chestnut specimen were compared to the values for the same type of tali specimen. The density values obtained for the chestnut specimens ranged from 433.6 to 690.5 $\mathrm{kg} / \mathrm{m}^{3}$ (for nearly a $60 \%$ rise from minimum to maximum) and for tali wood from 747.4 to $986.9 \mathrm{~kg} / \mathrm{m}^{3}$ (for a difference of around 30\% between minimum and maximum). This variation should have been reflected, firstly, in the same type of specimens made from the same wood species. To verify this assumption, the ultimate load values for each sample of each type of specimen were compared to the density of the wood with which the specimen was made. By way of example, Figure 3 compares the ultimate load values obtained for the type 5 chestnut specimens. Similar results were found for the other types of specimens made from both species of wood. The comparison showed that the two 


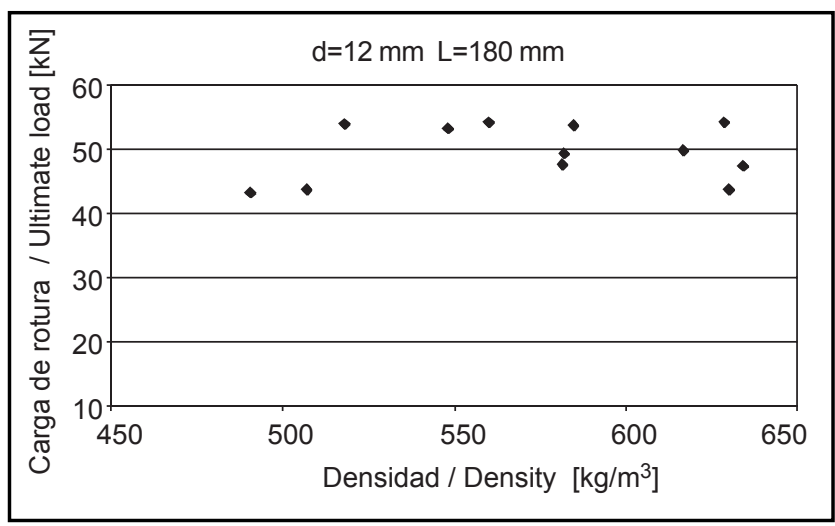

Figura 3. Relación entre la densidad de la madera $\left[\mathrm{kg} / \mathrm{m}^{3}\right]$ y los valores de carga de rotura para probetas de castaño realizadas con barras de $12 \mathrm{~mm}$ y una longitud de anclaje de $180 \mathrm{~mm}$.

Figure 3. Wood density $\left[\mathrm{kg} / \mathrm{m}^{3}\right]$ versus ultimate load for chestnut specimens with $12-\mathrm{mm}$ bars and a $180-\mathrm{mm}$ anchorage.

ambos parámetros (densidad y resistencia de la unión), obteniéndose valores de carga similares para uniones realizadas con probetas de densidades significativamente diferentes.

En segundo término, se estudió la influencia de la densidad considerando las dos especies de madera estudiadas, evaluando la posibilidad de una concordancia en valores estadísticos. Los valores característicos ( $5^{\circ}$ percentil) de densidad fueron de $796,2 \mathrm{~kg} / \mathrm{m}^{3}$ para el elondo y de $496,5 \mathrm{~kg} / \mathrm{m}^{3}$ para el castaño, lo que supone una relación del $160 \%$. Si se comparan valores medios la relación es del 154\% $(867,5 / 561,5)$.

Para evaluar la correspondencia entre la resistencia de la unión y la densidad, sería necesario que los valores de rotura alcanzados por las probetas de elondo fuesen superiores a 1,5 veces los alcanzados por las probetas de castaño.

En la Tabla 3 se han resumido los valores estadísticos alcanzados por los 10 tipos de probetas ensayados con ambas especies de madera. Las dos últimas columnas indican la relación entre los valores característicos y medios, respectivamente, obtenidos para las probetas de elondo y para probetas de castaño. Como puede verse, no existe una relación directa entre los resultados correspondientes a ambas especies; y sólo en dos de los diez tipos de probetas ensayadas los valores de rotura del elondo están en torno al $160 \%$ de los obtenidos para las probetas de castaño. En los ocho tipos restantes el porcentaje varía significativamente, bien por exceso, bien por defecto. Esta ausencia de relación entre la densidad de las dos especies de madera utilizada y los resultados de carga obtenidos se hace muy patente en la Figura 2 , que muestra los resultados obtenidos por cada uno de los especímenes de probetas realizadas con barras de $10 \mathrm{~mm}$. En dicha Figura se observa que, por ejemplo, para probetas realizadas con barras de $10 \mathrm{~mm}$ y una longitud de anclaje de $60 \mathrm{~mm}$, los valores de rotura son comparables con independencia de las características de la madera. parameters (density and bond strength) were apparently unrelated, for similar load values were obtained for specimens with significantly different densities.

The effect of density was then studied by comparing the two species of wood to determine the possibility of statistical concordance. The characteristic (5th percentile) values were $796.2 \mathrm{~kg} / \mathrm{m}^{3}$ for tali and 496.5 $\mathrm{kg} / \mathrm{m}^{3}$ for chestnut, i.e., a ratio of 1.6 . The ratio for the mean values (867.5/561.5) was 1.54 .

If density and bond strength were to be related, the failure values observed for tali wood would have to be 1.5 times greater than the loads found for chestnut specimens.

Table 3 summarizes the statistics for the 10 types of specimens of both types of wood. The last two columns denote the ratio percentage relationship between the characteristic and mean ultimate load values, respectively, obtained for the tali and chestnut specimens. Note that no direct relationship exists between the results for the two species, as the failure values for tali wood were on the order of $160 \%$ of the chestnut values in only two of the ten types of specimens. The percentage was significantly higher or lower than that figure in the remaining eight types. This absence of any relationship between the density of the two species of wood used and the load values obtained is clearly observed in Figure 2, which shows the findings for each of the 10-mm specimens. As noted earlier, the 10- $\mathrm{mm}$ specimens with an anchorage length of $60 \mathrm{~mm}$ had comparable failure values regardless of wood type. 
Tabla 3 / Table 3

Relación entre los valores obtenidos por las dos especies de madera utilizadas respecto a carga de rotura [en kN] y tensión promedio de corte [en $\mathrm{N} / \mathrm{mm}^{2}$ ] en la superficie madera-adhesivo.

Mean ultimate load [in $\mathrm{kN}$ ] and shear stress values [in $\mathrm{N} / \mathrm{mm}^{2}$ ] at the wood-adhesive surface for chestnut and tali wood specimens.

\begin{tabular}{|c|c|c|c|c|c|c|c|c|c|c|}
\hline \multirow[b]{2}{*}{$\begin{array}{c}\text { Tipo de } \\
\text { probeta / } \\
\text { Specimen } \\
\text { type }\end{array}$} & \multicolumn{4}{|c|}{$\begin{array}{c}\text { Resultados para probetas de castaño / } \\
\text { Results of chestnut specimens }\end{array}$} & \multicolumn{4}{|c|}{$\begin{array}{c}\text { Resultados para probetas de elondo / } \\
\text { Results of tali specimens }\end{array}$} & \multicolumn{2}{|c|}{$\begin{array}{l}\text { Comparación especies I } \\
\text { Ratio between species }\end{array}$} \\
\hline & $\begin{array}{c}\text { Valor de } \\
\text { rotura } \\
\text { medio / } \\
\text { Mean } \\
\text { ultimate } \\
\text { load }\end{array}$ & $\begin{array}{c}\text { Valor de } \\
\text { rotura } \\
\text { caracterís- } \\
\text { tico (50 } \\
\text { percentil) / } \\
\text { Characteris- } \\
\text { tic failure } \\
\text { load }\end{array}$ & $\begin{array}{c}\text { Tensión } \\
\text { de corte } \\
\text { promedio } \\
\text { madera- } \\
\text { adhesivo / } \\
\text { Mean } \\
\text { shear } \\
\text { stress } \\
\text { wood- } \\
\text { adhesive }\end{array}$ & \begin{tabular}{|c|} 
Tensión \\
de corte \\
caract. \\
madera- \\
adhesivo / \\
Characteris- \\
tic shear \\
stress \\
wood- \\
adhesive
\end{tabular} & $\begin{array}{c}\text { Valor de } \\
\text { rotura } \\
\text { medio / } \\
\text { Mean } \\
\text { ultimate } \\
\text { load }\end{array}$ & $\begin{array}{c}\text { Valor de } \\
\text { rotura } \\
\text { caract. (50 } \\
\text { percentil) } \\
\text { / Characte- } \\
\text { ristic } \\
\text { ultimate } \\
\text { load }\end{array}$ & $\begin{array}{c}\text { Tensión de } \\
\text { corte } \\
\text { promedio } \\
\text { madera- } \\
\text { adhesivo / } \\
\text { Mean shear } \\
\text { stress } \\
\text { wood- } \\
\text { adhesive }\end{array}$ & $\begin{array}{c}\text { Tensión } \\
\text { de corte } \\
\text { característ. } \\
\text { madera- } \\
\text { adhesivo / } \\
\text { Characteris- } \\
\text { tic shear } \\
\text { stress } \\
\text { wood- } \\
\text { adhesive }\end{array}$ & $\begin{array}{c}\text { Relación } \\
\text { entre los } \\
\text { valores } \\
\text { medios / } \\
\text { Ratio } \\
\text { between } \\
\text { mean } \\
\text { values }\end{array}$ & $\begin{array}{c}\text { Relación } \\
\text { entre los } \\
\text { valores } \\
\text { característ. } \\
\text { / Ratio } \\
\text { between } \\
\text { characteris- } \\
\text { tic values }\end{array}$ \\
\hline 01 & 27.09 & 13.14 & 10.26 & 4.98 & 27.72 & 20.77 & 10.5 & 7.87 & $102.33 \%$ & $158.07 \%$ \\
\hline 02 & 41.26 & 28.05 & 10.42 & 7.09 & 43.78 & 36.67 & 11.06 & 9.26 & $106.11 \%$ & $130.73 \%$ \\
\hline 03 & 45.92 & 36.63 & 8.7 & 6.94 & 57.53 & 47.84 & 10.9 & 9.06 & $125.28 \%$ & $130.60 \%$ \\
\hline 04 & 47.67 & 34.74 & 7.23 & 5.27 & 80.35 & 70.58 & 12.18 & 10.7 & $168.55 \%$ & $203.17 \%$ \\
\hline 05 & 49.44 & 40.28 & 6.25 & 5.09 & 82.68 & 74.95 & 10.44 & 9.47 & $166.99 \%$ & $186.07 \%$ \\
\hline 06 & 23.20 & 13.13 & 10.26 & 5.81 & 22.75 & 16.73 & 10.06 & 7.39 & $98.06 \%$ & $127.42 \%$ \\
\hline 07 & 30.12 & 19.13 & 8.88 & 5.64 & 39.87 & 32.31 & 11.75 & 9.52 & $132.37 \%$ & $168.90 \%$ \\
\hline 08 & 35.85 & 25.66 & 7.92 & 5.67 & 48.93 & 34.17 & 10.82 & 7.55 & $136.49 \%$ & $133.16 \%$ \\
\hline 09 & 36.25 & 28.23 & 6.41 & 4.99 & 54.63 & 41.28 & 9.66 & 7.3 & $150.70 \%$ & $146.23 \%$ \\
\hline 10 & 38.49 & 30.66 & 5.67 & 4.52 & 43.60 & 34.48 & 7.73 & 5.08 & $136.24 \%$ & $112.46 \%$ \\
\hline
\end{tabular}

No obstante, los resultados también evidencian, comparando valores medios o valores característicos de rotura, que las uniones realizadas en madera de elondo mostraron mayor capacidad resistente que las realizadas en madera de castaño. Pero, puesto que el análisis comparativo realizado con probetas de la misma especie (e ilustrado a modo de ejemplo en la Figura 3) pone de manifiesto que no existe una relación lineal entre la densidad de la madera y la capacidad resistente de la unión, parece plausible considerar que la diferencia de resultados entre ambas especies esté más relacionada con las características mecánicas de cada una de ellas que con sus densidades respectivas.

En este sentido, y considerando que el fallo predominante está asociado al fallo por cortante en la madera adyacente a la línea de encolado, se ha estudiado el valor de tensión de corte promedio que se produce en la superficie crítica madera-adhesivo (calculada como la relación entre la carga de rotura y la superficie de encolado). En este aspecto existía también una diferencia significativa entre las propiedades mecánicas de las dos especies de madera utilizadas. La relación entre los valores de resistencia a cortante de ambas especies es de aproximadamente un $128 \%$, considerando una resistencia a corte de $10 \mathrm{~N} / \mathrm{mm}^{2}$ para el elondo y de $7,8 \mathrm{~N} / \mathrm{mm}^{2}$ para la madera de castaño (14-15). De acuerdo con el análisis de la Tabla 3, se observa que esta relación entre características mecánicas podría estar más próxima a la obtenida para la capacidad de la unión en ambas maderas que la planteada en términos de densidades.
A comparison of the mean or characteristic failure values also showed, however, that the tali wood bonds were stronger than the chestnut joints. Nonetheless, since the comparison between specimens of the same species (as illustrated by way of example in Figure 3) indicated the absence of any linear relationship between wood density and bond axial strength, the difference in the values found for the two species may plausibly be due more to their mechanical characteristics than their respective densities.

In this regard, and inasmuch as the predominant failure mode was associated with shear stress in the wood adjacent to the layer of glue, a study was run on the mean shear stress generated at the critical woodadhesive surface (calculated to be the relationship between ultimate load and area of the glued surface). A significant difference was also found in this regard between the mechanical properties of the two species of wood used. The ratio between the shear strength of the two species was approximately $128 \%$, assuming a shear strength of $10 \mathrm{~N} / \mathrm{mm}^{2}$ for tali wood and $7.8 \mathrm{~N} / \mathrm{mm}^{2}$ for chestnut (14-15). Further to the data in Table 3, this ratio between the mechanical characteristics would be closer to the bond strength ratio between the two species than the ratio found for their respective densities. 
En la Tabla 3 se resumen los valores característicos de tensión de corte promedio en la superficie de encolado de la madera. Los resultados indican que, para ambas especies, esos valores de tensión de corte están próximos a la resistencia a cortante de la madera cuando utilizamos uniones cortas y van disminuyendo a medida que aumentamos la longitud de anclaje, confirmando nuevamente los planteamientos teóricos de Volkersen apuntados en apartados previos. Este aspecto se acusa más en las uniones realizadas con barras más delgadas.

En todo caso, no existe una relación constante para todos los tipos de probetas entre los valores de rotura obtenidos para ambas especies; por tanto, tampoco se cumple una relación constante unívoca entre la resistencia a cortante de la madera y el valor de corte promedio obtenido para cada tipo de probeta, lo que apunta a que será necesario considerar también otros factores en el diseño de la unión para evaluar la diferencia de resultados, además de las características resistentes de la madera.

\subsection{Comparación con los valores de cálculo propuestos por el Eurocódigo 5 para madera laminada}

En la Tabla 2 se resumen los valores obtenidos a partir de la propuesta del Eurocódigo 5 (1-3) para cada uno de los tipos de probeta ensayados, diferenciando las dos especies de madera utilizadas en base a la diferencia existente en su densidad característica. Para las probetas realizadas con madera de frondosa de densidad media (madera de castaño), la propuesta recogida a modo de Anexo Informativo en Eurocódigo 5 propone valores inferiores a los obtenidos experimentalmente. No obstante, cuando se utiliza madera de densidad elevada (madera de elondo) son los valores teóricos los que superan a los reales, avalando nuevamente la hipótesis planteada respecto a que la capacidad resistente de las uniones no puede evaluarse a partir de la variación en la densidad de la madera utilizada.

En la Figura 2 se representan estos resultados en relación con los valores experimentales obtenidos para probetas realizadas con barras de $10 \mathrm{~mm}$ (tipos 6 a 10). Esta imagen pone claramente de manifiesto que, al margen de las diferencias cuantitativas existentes entre los valores teóricos y los valores experimentales, existen diferencias cualitativas respecto a la incidencia de los parámetros considerados en el cálculo y su relación real con la resistencia de las uniones, tal y como se ha mostrado en los apartados previos; puesto que como se ha demostrado no se cumple la linealidad propuesta entre capacidad de carga y longitud de anclaje o la superficie de encolado de la madera.
Table 3 summarizes the mean characteristic shear stress values at the glued surface. The findings indicated that for both species, these stress values were near the wood's shear strength in short bond specimens but declined as the anchorage length rose. This observation would again confirm Volkersen's theoretical premises discussed above and was more visible in the bonds with narrower bars.

In any event, in the absence of any consistent relationship between the two species in all the specimen types, no constant, one-to-one relationship can be said to exist between wood shear strength and the mean shear value obtained for each type of specimen. Consequently, other factors in addition to wood strength will have to be considered in bond design to evaluate this variability in the results.

\subsection{Comparison to the design values proposed by Eurocode 5 for laminated timber}

Table 2 summarizes the values obtained using the Eurocode 5 proposal (1-3) for each specimen type, using the characteristic density value for each species. For the specimens made with medium density hardwood (chestnut), the informative annex to Eurocode 5 proposes values lower than the experimental findings. When high density wood (tali) was used, however, the theoretical values were higher than the experimental findings, confirming that bond axial strength cannot be assessed on the grounds of the variation in wood density.

In Figure 2 these results are compared to the experimental values obtained for specimens with $10-\mathrm{mm}$ bars (types 6 to 10). The resulting graph clearly shows quantitative differences between the theoretical and experimental values. In addition, however, as discussed above, qualitative differences can be observed between the assumed and actual impact of the design proposal parameters on bond strength, for the experimental findings did not confirm the proposed linearity between load capacity and anchorage length or area of the glued surface. 


\section{CONCLUSIONES}

El análisis de los resultados obtenidos en una amplia campaña experimental de ensayo de uniones realizadas con barras roscadas de acero encoladas con epoxi en madera de frondosa, nos permite obtener las siguientes conclusiones relativas a la posible influencia de los parámetros geométricos y las propiedades de la madera en la capacidad resistente de las uniones encoladas.

Los defectos puntuales existentes en la madera, principalmente nudos y fendas, no precipitaron, en ningún caso, el fallo de las probetas, aún a pesar de no poder contar con madera de frondosa clasificada. Tampoco se encontró relación alguna entre el desarrollo de la fractura en la madera y la presencia de estos fallos locales.

Los resultados mostraron que no puede establecerse una relación lineal entre la superficie crítica de encolado de la madera y la capacidad de carga de las uniones, confirmando los planteamientos enunciados en la llamada teoría de Volkersen, según la cual uniones con longitudes de encolado mayores (y por tanto más rígidas) presentan distribuciones de tensiones de corte menos uniformes, debido a los picos de tensión que se originan en los extremos.

En relación con las propiedades de la madera, los resultados obtenidos experimentalmente han constatado la ausencia de una correspondencia unívoca entre la densidad de la madera y la capacidad de carga de la unión, contradiciendo los planteamientos de las propuestas de cálculo que utilizan este parámetro para determinar la carga, entre las que se encuentra la del Eurocódigo 5, en su versión de borrador final prEN 1995-1-1(2001).

Por el contrario, se observó una relación entre la capacidad de la unión y la resistencia a cortante de la madera. Las tensiones de corte promedio en la unión estaban próximas a esta propiedad mecánica del material en uniones de pequeña longitud, y disminuían significativamente para longitudes de encolado mayores. No obstante, tampoco se encontró una relación lineal entre los valores de tensión de corte promedio de rotura obtenidos para las dos especies de madera, lo que parece indicar que la longitud de la unión tiene una incidencia variable dependiendo de las características mecánicas de la madera utilizada.

Los valores de carga de rotura alcanzados por las probetas se han comparado además con los valores de cálculo propuestos por el Eurocódigo 5 en su versión de borrador final prEN 1995-1-1 (2001), lo que ha puesto de manifiesto, además de diferencias cuantitativas, importantes diferencias cualitativas en los criterios de diseño considerados. Los resultados obtenidos confirman la

\section{CONCLUSIONS}

The following conclusions on the possible effect of geometric parameters and wood properties on glued joint axial strength may be drawn from the findings of the present analysis of the bonds formed when threaded steel bars are glued to hardwood with epoxy resin.

Although classified hardwood was not available, the occasional flaws in the wood used, primarily knots and fissures, did not precipitate failure in any of the specimens, nor was any relationship found between fracture development in the wood and the presence of such local flaws.

The findings showed that no linear relationship can be drawn between the area of the critical glued wood surface and bond load capacity. This confirmed the socalled Volkersen theory, according to which bonds with longer (and hence stiffer) anchorages exhibit less uniform shear stresses due to the higher stress generated at the two ends.

In another vein, the experimental findings corroborated the absence of any one-to-one relationship between wood density and bond load capacity, contradicting the assumptions underlying design proposals that use this parameter to determine the ultimate load. One such proposal is to be found in the draft version of Eurocode 5, prEN 1995-1-1(2001).

By contrast, a relationship was observed to exist between bond capacity and wood shear strength. The mean shear stress on the bond was close to the shear strength in materials with short anchorages, but declined significantly with rising anchorage lengths. Nonetheless, the absence of any linear relationship between the mean shear failure values for the two species of wood may appear to imply that bond length has a variable effect depending on the mechanical characteristics of the wood used.

A comparison of the ultimate load values attained by the specimens to the design values proposed in the final draft version of Eurocode 5 (prEN 1995-1-1 (2001)) showed not only quantitative but also substantial qualitative differences. These findings confirm the need for further experimental research on high density hardwood bonds to establish design criteria in keeping 
necesidad de profundizar en el análisis experimental de uniones realizadas en madera de frondosa de densidad elevada, para establecer criterios de diseño adaptados a su comportamiento real, puesto que la experiencia pone de manifiesto sus elevadas prestaciones resistentes.

\section{AGRADECIMIENTOS}

Ministerio de Ciencia y Tecnología, proyecto de investigación: "Uniones metálicas encoladas con adhesivos en barras de madera". Referencia DPI2002-02390. with their actual behaviour, in light of the high performance this type of joints has been observed to deliver in real situations.

\section{BIBLIOGRAFÍA / BIBLIOGRAPHY}

(1) CEN/TC 250/SC5. Eurocode 5. Desing of timber structures. Part 1.1. General rules. General rules and rules for building. Final draft prEN 1995-1-1 (2001).

(2) Estévez Cimadevila, J.; Vázquez Rodríguez, J. A.; Otero Chans, M. D.: "Experimental behaviour of threaded steel rods glued into high-density hardwood", International Journal of Adhesion and Adhesives, volume 27, issue 2 (2007), pp. 136-144. doi:10.1016/j.ijadhadh.2006.01.006

(3) UNE 56531-77. Características físico-mecánicas de la madera. Determinación del peso específico.

(4) Tesis doctoral: "Barras roscadas de acero encoladas en madera de frondosa", Universidad de La Coruña (2007).

(5) Buchanan, A.; Moss, P.: "Desing of epoxied steel rods in glulam timber", PTEC'99. Pacific Timber Engineering Conference, 14-18 March 1999, Rotorua, New Zealand, Proceeding Volume 3, Edited by G. Walford, B. \& Gaunt, D. J., Forest Research Bulletin no 212 (1999), pp. 286-293.

(6) Deng, J. X.; Moss, P. J.; Buchanan, A. H.: "Glued Bolts in Glulam - An analysis of stress distribution", 50 World Conference on Timber Engineering, Montreux, Switzerland (1998).

(7) Riberholt, H.: Glue Bolts in Glulam, University of Denmark (1986), Serie R: 210.

(8) Blaß, H. J.; Laskewitz, B.: Glued-in rods for timber structures - GIROD, Universität Karlsruhe (TH) (2002).

(9) Aicher, S.; Höfflin, L.; Wolf, M.: "Influence of specimen geometry on stress distributions in pull-out tests of glued-in steel rods in wood", Otto-Graf-Journal, vol. 9, FMPA, Stuttgart, Germany (1998).

(10) UNE-EN 408:1995. Estructuras de madera. Madera aserrada y madera laminada encolada para uso estructural. Determinación de algunas propiedades físicas y mecánicas.

(11] Código Técnico de la Edificación. Documento Básico de Seguridad estructural. Bases de cálculo, RD 314/2006 (2006).

(12) Volkersen, O.: "Die Schubkraftverteilung in Leim, Niet und Bolzenverbindungen". Energie und Technik 68-71, 103-108, 150-154 (1953).

(13) Gerold, M.: "Verbund van Holz und Gewindestangen aus Stahl", Bautechnik, 69 (4) (1992), pp. 167-178.

(14) VV.AA. "Especies de maderas para carpintería, construcción y mobiliario", Asociación de Investigación Técnica de las industrias de la Madera y Corcho, AITIM (1997).

(15) Cigalat Figuerola, E.; Soler Burillo, M.: Guía de las principales maderas y de su secado, Ediciones Mundi-Prensa, Madrid (2003). 